\title{
Isolation of a Bovine Rotavirus with a "Super-Short" RNA Electrophoretic Pattern from a Calf with Diarrhea
}

\author{
PREM S. PAUL, ${ }^{1 *}$ YOUNG S. LYOO ${ }^{1} \dagger$ GERALD N. WOODE, ${ }^{2}$ SHILUN ZHENG ${ }^{2}$ HARRY B. GREENBERG, ${ }^{3}$ \\ SUZANNE MATSUI, ${ }^{3}$ KENT J. SCHWARTZ, ${ }^{4}$ AND HOWARD T. HILL ${ }^{4}$ \\ Veterinary Medical Research Institute ${ }^{1}$ and Veterinary Diagnostic Laboratory, ${ }^{4}$ College of Veterinary Medicine, Iowa \\ State University, Ames, Iowa 50011; Department of Veterinary Microbiology and Parasitology, Texas A \& M University, \\ College Station, Texas $77843^{2}$; and Gastroenterology Division, Veterans Administration Medical Center, \\ Palo Alto, California $94304^{3}$
}

Received 25 February 1988/Accepted 11 July 1988

\begin{abstract}
A rotavirus with a "super-short" RNA electropherotype was isolated from a calf with diarrhea and was designated VMRI strain. Segments 10 and 11 of this rotavirus migrated more slowly than did those of bovine rotavirus strains NCDV, B641, and B223. The electrophoretic pattern of the VMRI strain was similar to that reported for rotaviruses with super-short RNA electropherotypes from humans and rabbits. Northern (RNA) blot hybridization indicated that gene 11 of the VMRI strain was altered and migrated between gene segments 9 and 10. The subgroup of the VMRI strain was shown to be subgroup I. The VMRI strain of bovine rotavirus was neutralized by antisera containing polyclonal antibodies to rotavirus serotype 6 (bovine rotavirus serotype I) strains NCDV and B641 and by ascitic fluid containing monoclonal antibodies directed to VP7 of serotype 6 rotavirus. The VMRI strain was not neutralized by either polyclonal or monoclonal antibodies to strain B223 (bovine rotavirus serotype II). Collective data on the neutralization of the VMRI strain with monoclonal antịbodies and polyclonal antibodies suggest that this virus is a member of the NCDV group (serotype 6) of rotaviruses (bovine rotavirus serotype $\mathbf{I}$ ).
\end{abstract}

Rotaviruses are major causes of enteric disease in animals and humans $(4,7,8,10,11,27,37)$. Although there are several antigenically and electrophoretically distinct groups (A through E) of rotaviruses $(2,3,31-33)$, group A rotaviruses appear to be the most prevalent. Group A rotaviruses share a common group antigen on protein VP6 (38). Two subgroups of group A rotaviruses have been reported (15). Neutralizing antigens are contained in two proteins, VP3 and VP7 (16), which also provide serotypic specificity (16). Hoshino et al. (19) reported seven group A rotavirus serotypes based on a minimum of 20 -fold differences between the neutralizing titers of antisera with homologous and heterologous viruses. Only serotype 6 (bovine rotavirus serotype I) with an NCDV strain serving as a prototype has been detected in cattle (27). Strains UK, B-14, and B641 belong to this serotype $(19,37,39,40)$. Additional serotypes of bovine rotavirus have been detected $(5,6,20,28,30,34$, 40). One of these serotypes (bovine rotavirus serotype II) has been detected in U.S. cattle, with strain B223 serving as a prototype virus (40). There may also be additional serotypes of rotavirus in U.S. cattle (39).

Group A rotaviruses have a characteristic RNA electrophoretic pattern in polyacrylamide gels in which 11 segments of double-stranded (ds) RNA are arranged in four regions in groups of $4,2,3$, and 2 segments (22). The group A rotavirus common and subgroup antigens are coded for in gene segment $6(10,14)$. The neutralization antigens in proteins VP3 and VP7 are encoded by gene segments 4 and either 8 or 9 , respectively $(21,29)$. All of the bovine rotaviruses thus far reported have long RNA electropherotypes. However, rotaviruses with "super-short" RNA electropherotypes have recently been reported for humans and rabbits $(1,17,25,36)$.

\footnotetext{
* Corresponding author.

$\dagger$ Present address: Veterinary Research Institute, Anyang, South Korea.
}

In these viruses, gene segments 10 and 11 have slower electrophoretic mobilities (1). Human rotavirus with a supershort RNA pattern represents a new serotype $(1,25)$, whereas the rabbit rotavirus was shown to be a serotype 3 rotavirus (36). In this report, we describe isolation and preliminary characterization of a bovine rotavirus from a calf with diarrhea, designated VMRI strain, with a super-short RNA electrophoretic pattern.

\section{MATERIALS AND METHODS}

Case history. A dead, two-week-old Simmental calf from Missouri was submitted to the Iowa State University Veterinary Medical Diagnostic Laboratory. The calf developed diarrhea at 2 days of age and was treated with gentamicin, penicillin, and oral electrolytes. The calf responded but relapsed soon after therapy was discontinued. It was then treated intermittently for 13 days before it died at 15 days of age. Seven other calves died out of a total of ninety. Most of the calves went through episodes of diarrhea, but samples from these animals were not available for investigation.

Diagnostic tests for viral antigens. Intestinal contents were tested for rotavirus common antigens by an enzyme-linked immunosorbent assay (Rotazyme II; Abbott Laboratories, North Chicago, Ill.) according to the protocol of the manufacturer.

RNA analysis. The electrophoretic pattern of genomic viral RNA was determined by polyacrylamide gel electrophoresis. Viral RNA was extracted from fecal samples by a procedure similar to that described by Herring et al. (18), except that all of the steps were performed by using a microcentrifuge. Briefly, 0.2-g fecal samples were diluted with $0.6 \mathrm{ml}$ of sodium acetate buffer, sonicated, and clarified by centrifugation at $13,000 \times g$ for $1 \mathrm{~min}$. The supernatants were harvested, extracted with $0.5 \mathrm{ml}$ of phenol-chloroform solution, and clarified by centrifugation at $13,000 \times g$ in a 
microcentrifuge for $1 \mathrm{~min}$. Electrophoresis of RNA segments was performed in Laemmli 0.75 -mm-thick polyacrylamide slab gels (23) with $10 \%$ resolving and $3.5 \%$ stacking gels. Electrophoresis was done at a constant current of $9 \mathrm{~mA}$ for $16 \mathrm{~h}$ at $4^{\circ} \mathrm{C}$, and gels were stained with silver (18). Cells infected with rotavirus were extracted with Freon (E. I. du Pont de Nemours \& Co., Wilmington, Del.) and pelleted through $30 \%$ sucrose at $100,000 \times g$ for $3 \mathrm{~h}$, and viral RNA was extracted with phenol-chloroform. Electropherotypes of viral RNA were analyzed by polyacrylamide gel electrophoresis.

Viral isolation. Rotavirus was isolated from intestinal contents in MA-104 cells in roller tube cultures as described previously (12). Briefly, $10 \%$ suspensions of intestinal contents were prepared in modified Eagle medium containing gentamicin $(50 \mu \mathrm{g} / \mathrm{ml})$, sonicated, clarified by centrifugation at $400 \times g$ for $10 \mathrm{~min}$, and filtered through $0.45-\mu \mathrm{m}$ filters. The inoculum was pretreated with $10 \mu \mathrm{g}$ of trypsin (type IX; Sigma Chemical Co., St. Louis, Mo.) per ml for $1 \mathrm{~h}$ at $37^{\circ} \mathrm{C}$. The inoculum was adsorbed onto cultures of MA-104 cells in roller tubes. After adsorption for $1 \mathrm{~h}$, the monolayers were washed twice with modified Eagle medium and the culture medium was replaced with modified Eagle medium supplemented with trypsin $(0.5 \mu \mathrm{g} / \mathrm{ml})$ and gentamicin $(50 \mu \mathrm{g} / \mathrm{ml})$ without serum. Mock-infected cells were treated similarly, except that modified Eagle medium containing trypsin was substituted for viral inoculum. The cultures were examined for cytopathic effect daily. Once cytopathic effect was extensive, cultures were frozen and thawed twice and passaged once more in roller tube cultures. A third-passage virus stock was prepared and used for characterization. Bovine rotavirus strains NCDV, B641, and B223 were propagated in MA-104 or BSC-1 cells.

Antisera and monoclonal antibodies. Bovine rotaviruses were propagated in MA-104 cells (VMRI strain) or BSC-1 cells (B641, NCDV, and B223). Virions were purified on cesium chloride gradients (26), and double-capsid virions were used to prepare hyperimmune serum in guinea pigs against strains VMRI and NCDV. Production of antisera to B223 (GC47), B641 (GC51), and NCDV (GC54) in gnotobiotic calves and antisera to B14, canine serotype 3 virus, and OSU-1 (a porcine virus) in guinea pigs has been described previously $(12,13,38,39)$. Monoclonal antibody IC3 was directed to VP7 of NCDV and monoclonal antibody HRB223 had specificity for VP3 of B223 virus.

Virus neutralization. Neutralization was performed by a fluorescent focus neutralization test as described previously (40). Briefly, samples of rotavirus containing about 200 fluorescent-focus-forming units were mixed with equal volumes of culture medium or with dilutions of antisera and incubated at $37^{\circ} \mathrm{C}$ for $1 \mathrm{~h}$. The virus-serum mixture $(0.1 \mathrm{ml})$ was inoculated into each of four wells of cells on 96-well microdilution plates. At $24 \mathrm{~h}$ after infection, the cells were fixed and stained for rotavirus antigen by an indirect immunofluorescence test. The neutralization titer was the reciprocal of the highest dilution of serum that neutralized $50 \%$ or more of the virus. Results are reported as the mean neutralizing titer of the four determinations.

Northern blot hybridization. Approximately $10 \mu \mathrm{g}$ of dsRNA was extracted from VMRI and NCDV bovine rotavirus particles purified by cesium chloride density gradients (26). The dsRNA segments of the viral genome were separated by polyacrylamide gel electrophoresis as described by Laemmli (23). The dsRNA was denatured partially and transferred electrophoretically to nylon membranes (BioRad Laboratories, Richmond, Calif.) according to the in- structions of the manufacturer. Northern (RNA) blot hybridizations were done by using ${ }^{32} \mathrm{P}$-labeled cDNA probes synthesized from templates of all 11 genes of genomic RNAs or from the single gene 10 or gene 11 of NCDV. The probes were synthesized from RNA with reverse transcriptase by using random primers (Pharmacia, Inc., Piscataway, N.J.) as described by Eiden et al. (8). Hybridization conditions were adapted from Dimitrov et al. (7). After overnight hybridization at $65^{\circ} \mathrm{C}$, the membranes were washed as specified by Dimitrov et al. (7), except that the final wash was at $65^{\circ} \mathrm{C}$ with $1 \times \operatorname{SSC}(0.15 \mathrm{M} \mathrm{NaCl}$ plus $0.015 \mathrm{M}$ sodium citrate). The filters were then exposed to XAR film (Eastman Kodak Co., Rochester, N.Y.).

Detection of subgroup antigen. Rotavirus group A subgroup antigens were determined by a modification of an enzyme-linked immunosorbent assay described by Greenberg et al. (15). Briefly, wells of microdilution plates (Immulon-I; Dynatech, Chantilly, Va.) were coated with 1:1,000 dilutions each of rabbit anti-OSU-1 and anti-Gottfried porcine rotavirus antisera in carbonate-bicarbonate buffer. After overnight incubation at $4^{\circ} \mathrm{C}$, the plates were washed, and the free sites were blocked with $1 \%$ bovine serum albumin in phosphate buffer and $0.1 \%$ Tween 20 . Rotavirus diluted 1:2 in phosphate buffer-Tween 20-bovine serum albumin was added to wells and incubated for $16 \mathrm{~h}$ at $4^{\circ} \mathrm{C}$. The wells were washed, and monoclonal antibodies (provided by $Y$. Hoshino, National Institutes of Health, Bethesda, Md.) reactive with group A rotavirus, subgroup I (255/60/125/14) or subgroup II $(631 / 9 / 104 / 56)$, were added. After $2 \mathrm{~h}$ of incubation, the wells were washed and horseradish peroxidase-conjugated goat anti-mouse immunoglobulin $G$ was added. The reactions were developed by adding $0.2 \mathrm{ml}$ of a substrate-chromogen solution consisting of $2 \mathrm{mM}$ hydrogen peroxide and $0.2 \mathrm{mM}$ ABTS [2,2'-azino-di-(3-ethyl-benzy-

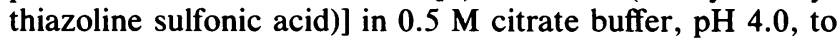
each well. The $\mathrm{A}_{405}$ was recorded after $30 \mathrm{~min}$ in an enzyme-linked immunosorbent assay reader (Biotech Instruments Inc., Winooski, Vt.). Results were expressed as optical density as well as subgroup ratio. The subgroup ratio was determined by dividing the optical density of the subgroup I monoclonal antibody by that of the subgroup II monoclonal antibody. A subgroup ratio of more than 3.0 was taken as rotavirus belonging to subgroup I, whereas OD ratios of less than 0.5 were indicative of rotavirus subgroup II. Porcine OSU-1 (subgroup I) and Gottfried (subgroup II) strains were used as controls.

\section{RESULTS AND DISCUSSION}

Intestinal contents were positive for rotavirus by enzymelinked immunosorbent assay and RNA electropherotyping. The VMRI strain of rotavirus had a 4,2,3,2 electrophoretic pattern typical of group A rotaviruses, except that in comparison with the NCDV, B641, and B223 strains of bovine rotavirus (Fig. 1), it had a super-short RNA electropherotype. Gene segments 10 and 11 of the VMRI strain migrated more slowly than did those of the NCDV, B641, and B223 strains, and the electropherotype of the cultivated virus was identical to that of the fecal virus. Minor differences in the migration of other segments were also observed among the NCDV, B641, B223, and VMRI strains (Fig. 1). Slow electrophoretic migration of gene segments 10 and 11 was similar to that described for super-short rotaviruses from humans and rabbits $(1,36)$.

There are two possible explanations for the slower electrophoretic migration of segments 10 and 11 of the VMRI 


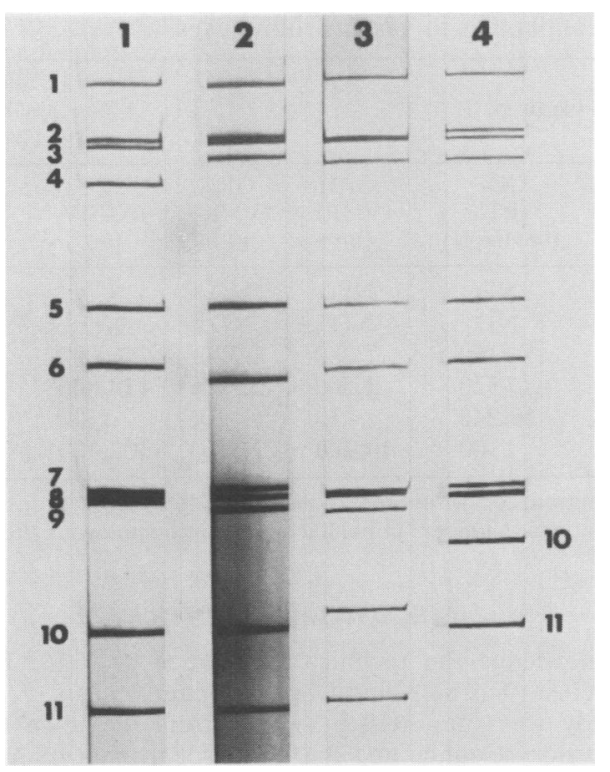

FIG. 1. Electrophoretic analysis of viral genomic RNAs from bovine rotavirus strains NCDV (lane 1), B641 (lane 2), B223 (lane 3), and VMRI (lane 4) in polyacrylamide gels stained with silver. Segments are numbered in relation to the order of migration. Note that segments 10 and 11 of the VMRI strain migrated considerably more slowly than did those of the other strains.

strain of rotavirus. Either both genes 10 and 11 are altered or only gene 11 is altered. Closer examination of the electrophoretic patterns suggested that only gene 11 of VMRI is altered, since it is similar in size to gene 10 of the NCDV, B641, and B223 strains. Additionally, in other rotaviruses with a short pattern, such as the DS-1 strain of human rotavirus, gene 11 is inverted in relation to gene 10 (for a review, see reference 10). To determine if gene 11 or both genes 10 and 11 were altered in the VMRI strain, Northern blots of viral RNA were hybridized with gene 10 or 11 probes. NCDV gene 10 probe hybridized to segment 11 of the VMRI strain (Fig. 2) and segment 10 of the NCDV strain (data not shown). NCDV gene 11 probe hybridized to segment 10 of the VMRI strain (Fig. 2) and segment 11 of the NCDV strain (data not shown), which indicated that gene 11 was altered in the VMRI strain and was longer and migrated more slowly than gene 11 in NCDV. Gene 11 of VMRI migrated between genes 9 and 10 . The biological significance of this alteration is unclear.

The VMRI strain contained the rotavirus group A subgroup I antigen but not the subgroup II antigen (Table 1). Control viruses OSU-1 (subgroup I virus) and Gottfried (subgroup II virus) were shown to contain subgroup I and II antigens, respectively (Table 1 ).

The VMRI strain of rotavirus was serotyped by a fluorescent focus neutralization test with antisera to the B641, NCDV, and B-14 strains, as well as to the VMRI strain (Table 2). Antiserum to serotype 3 canine rotavirus neutralized the VMRI strain to low titers (Table 2). Antisera to bovine rotavirus B223 and serotype 5 OSU-1 rotavirus did not neutralize VMRI. Anti-VMRI serum neutralized bovine rotaviruses NCDV and B641 but not B223; however, some differences were noted in the neutralization titers with the homologous and heterologous viruses. These data suggested that the VMRI strain is a member of the NCDV/B641 group of serotype 6 rotaviruses. To further study the relationship between the VMRI and NCDV strains, monoclonal antibod-

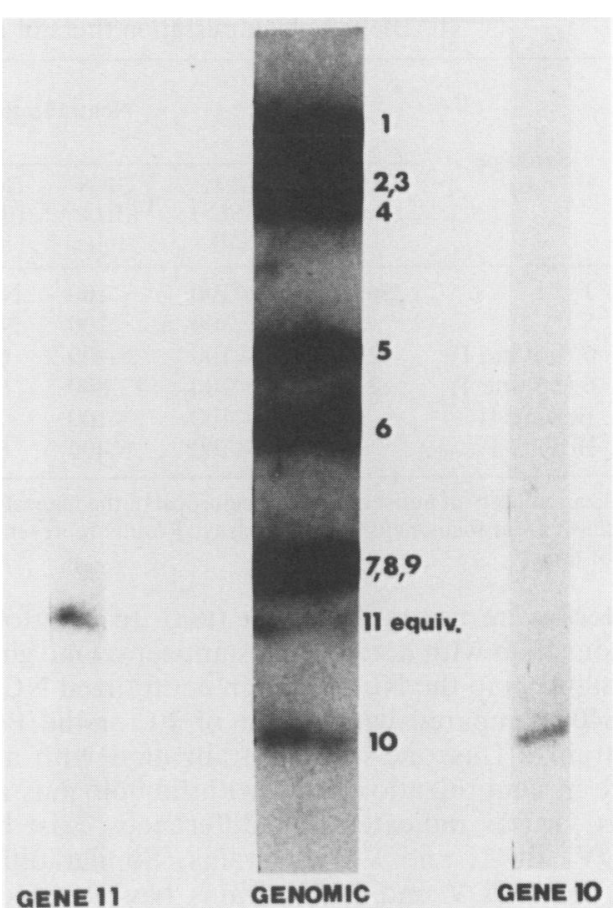

FIG. 2. Aberrant migration of the gene 11 equivalent of the VMRI strain of bovine rotavirus. Genomic dsRNA from the VMRI strain of bovine rotavirus was separated by polyacrylamide gel electrophoresis, partially denatured, and transferred to a nylon membrane. ${ }^{32}$ P-labeled probes of NCDV total genomic RNA (middle lane), gene 11 (left lane), and gene 10 (right lane) were hybridized to individual strips of blotted VMRI genomic RNA. The specific gene probes showed that the VMRI RNA segment that migrates as the 10th gene from the origin is identified by the NCDV gene 11 probe (left lane). Conversely, the NCDV gene 10 probe hybridizes to the VMRI RNA segment that migrates as the 11th gene (right lane).

ies IC3 and HRB223 were used in the neutralization test. Monoclonal antibody HRB223 neutralized B223 but did not neutralize the NCDV, B641, or VMRI strains of bovine rotavirus (Table 2). Monoclonal antibody IC3 had high neutralizing titers for the NCDV, B641, and VMRI strains (Table 2), but it did not neutralize strain B223.

The neutralization data in this study support the classification of the VMRI strain in the NCDV group of bovine rotaviruses. However, some antigenic differences were evident between the VMRI and NCDV strains, since neutrali-

TABLE 1. Results of enzyme-linked immunosorbent assay for the detection of subgroup antigen

\begin{tabular}{|c|c|c|c|c|}
\hline \multirow{2}{*}{ Virus } & \multicolumn{2}{|c|}{ Mean optical density ${ }^{a}$} & \multirow{2}{*}{$\begin{array}{l}\text { Subgroup } \\
\text { ratio }^{b}\end{array}$} & \multirow{2}{*}{$\begin{array}{l}\text { Subgroup } \\
\text { specificity }\end{array}$} \\
\hline & Subgroup I & Subgroup II & & \\
\hline $\begin{array}{l}\text { Culture fluid } \\
\text { (control; } \\
\text { no virus) }\end{array}$ & 0.014 & 0.017 & 0.82 & \\
\hline VMRI & 1.023 & 0.022 & 46.5 & I \\
\hline OSU-1 & 1.141 & 0.019 & 60.0 & I \\
\hline Gottfried & 0.026 & 1.073 & 0.02 & II \\
\hline
\end{tabular}

\footnotetext{
${ }^{a}$ Mean optical density at $405 \mathrm{~nm}$ from two wells.

${ }^{b}$ Mean optical density of monoclonal antibody 255/60/125/14 divided by that of monoclonal antibody 631/9/104/56. A ratio of $>3$ is indicative of subgroup I specificity; a ratio of $<0.5$ is indicative of subgroup II specificity.
} 
TABLE 2. Neutralization titers of antisera and monoclonal antibodies to various rotaviruses

\begin{tabular}{|c|c|c|c|c|c|c|c|c|c|c|c|c|}
\hline \multirow{2}{*}{ Virus } & \multirow{2}{*}{ Serotype } & \multicolumn{9}{|c|}{ Neutralization titer of antiserum ${ }^{a}$ (virus [serotype]) } & \multicolumn{2}{|c|}{$\begin{array}{l}\text { Neutralization titer of } \\
\text { monoclonal antibody } \\
\text { (virus [serotype]) }\end{array}$} \\
\hline & & $\begin{array}{l}\text { GP17 } \\
\text { (canine } \\
\text { [3]) }\end{array}$ & $\begin{array}{l}\text { GP41 } \\
\text { (OSU-1 } \\
[5])\end{array}$ & $\begin{array}{l}\text { GP38 } \\
\text { (B14 } \\
[6])\end{array}$ & $\begin{array}{c}\text { GC51 } \\
\text { (B641 } \\
[6])\end{array}$ & $\begin{array}{c}\text { GC54 } \\
\text { (NCDV } \\
[6])\end{array}$ & $\begin{array}{c}\text { GP2 } \\
\text { (NCDV } \\
[6])\end{array}$ & $\begin{array}{c}\text { GC47 } \\
\text { (B223 } \\
\text { [bovine II]) }\end{array}$ & $\begin{array}{l}\text { GP3 } \\
\text { (VMRI } \\
\text { [6]) }\end{array}$ & $\begin{array}{l}\text { GP4 } \\
\text { (VMRI } \\
\text { [6]) }\end{array}$ & $\begin{array}{l}\text { IC3 } \\
\text { (NCDV } \\
[6])\end{array}$ & $\begin{array}{l}\text { HRB223 } \\
\text { (B223 } \\
\text { [bovine II]) }\end{array}$ \\
\hline Canine & 3 & 256,000 & $<100$ & $<100$ & $\mathrm{ND}^{b}$ & ND & ND & ND & ND & ND & ND & ND \\
\hline OSU-1 & 5 & $<500$ & 12,800 & $<100$ & ND & ND & ND & ND & ND & ND & ND & ND \\
\hline B641 & 6 (bovine I) & 1,000 & $<100$ & 6,400 & 640 & 1,280 & 20 & 160 & 1,280 & 320 & 256,000 & $<1$ \\
\hline NCDV & 6 (bovine I) & 2,000 & $<100$ & 12,800 & 640 & 5,120 & 640 & 320 & 2,560 & 2,560 & 128,000 & $<1$ \\
\hline B223 & Bovine II & 500 & $<100$ & $<100$ & $<20$ & $<20$ & $<10$ & 10,240 & $<10$ & $<10$ & $<100$ & 1,024 \\
\hline VMRI & Bovine I & 500 & $<100$ & 6,400 & 640 & 1280 & 20 & $<100$ & 10,240 & 2,560 & 102,400 & $<1$ \\
\hline
\end{tabular}

${ }^{a}$ Neutralization titers of antisera are the reciprocal of the highest dilution of antisera which neutralized $50 \%$ or more of the virus ( 200 fluorescent-focus-forming units) in a fluorescent focus neutralization assay. Results represent the mean of four determinations. Numbers in boldface type are homologous titers.

${ }^{b}$ ND, Not done.

zation titers were generally higher (two- to eightfold) with homologous than with heterologous antisera. One guinea pig antiserum (GP2) to the NCDV strain neutralized NCDV at a titer of 640 , compared with a titer of 20 for the B641 and VMRI strains. This one-way neutralization with a 32 -fold difference in neutralization titers with homologous and heterologous viruses indicates that differences exist between the NCDV, B641, and VMRI strains. Similar differences between the NCDV and B641 strains have been detected previously with selected antisera (40). Furthermore, the NCDV and B641 strains do not induce cross-protective immunity, although they belong to the same serotype (40). Studies on cross protection between the NCDV and VMRI strains are needed to further evaluate the antigenic relatedness between these two viruses and to develop strategies for immunizing cattle against rotavirus-induced diarrhea. Detailed characterization of the outer viral proteins and genomic segments of the super-short-pattern rotaviruses and their comparison with long-pattern bovine rotaviruses are needed to determine the biological significance of supershort-pattern rotaviruses. Some investigators believe that gene 11 codes for an outer protein (9) and possibly a minor neutralization antigen (24), whereas others contend that it codes for a nonstructural protein (1).

Although rotaviruses with super-short RNA electropherotypes have been isolated from humans in Indonesia $(1,17$, 25), from rabbits in the U.S. (36), and now from a single calf in the U.S., their prevalence and incidence have not been determined. We have recently detected an additional isolate of bovine rotavirus with a super-short electropherotype from a herd of cattle in Iowa. This isolate was a mixture of rotaviruses with long and super-short RNA electropherotypes. Rotaviruses with a super-short RNA electropherotype have also been detected from cattle in Utah (J. W. Lopez, S. A. Allen, W. Jones, and Y. Elsner, Proc. Conf. Res. Workers Animal Diseases, Chicago, Ill., abstract no. $84,1987)$ and Idaho $(35)$. The latter virus isolate from Idaho (35) was shown to be distinct serotypically from the NCDV group of bovine rotaviruses. Studies are in progress in our laboratory to determine the prevalence of rotavirus serotypes, including rotaviruses with super-short RNA electropherotypes, in cattle populations.

This study documents the presence of a rotavirus with a super-short RNA electropherotype in cattle. This unique electrophoretic pattern was shown to be due to the altered mobility of gene 11, which migrated between genes 9 and 10 . Serotyping results indicate that rotaviruses with super-short RNA electropherotypes do not necessarily represent new serotypes of rotaviruses.

\section{ACKNOWLEDGMENTS}

We acknowledge the technical assistance provided by Renee Pippert, Denise Warriner, and Don Anderson.

This study was supported by grants from the Iowa Livestock Health Advisory Council and the U.S. Department of Agriculture Formula Funds (1433 Section of the 1985 Farm Bill). Financial support for Y. S. Lyoo was provided by a research fellowship from the Food and Agricultural Organization.

\section{LITERATURE CITED}

1. Albert, M. J., L. E. Unicomb, and R. F. Bishop. 1987. Cultivation and characterization of human rotaviruses with "super short" RNA patterns. J. Clin. Microbiol. 25:183-185.

2. Arias, C. F., S. Lopez, and R. T. Espejo. 1982. Gene protein products of SAll simian rotavirus genome. J. Virol. 41:42-50.

3. Bohl, E. H., L. J. Saif, K. W. Theil, A. G. Agnes, and R. F. Cross. 1982. Porcine pararotavirus: detection, differentiation from rotavirus, and pathogenesis in gnotobiotic pigs. J. Clin. Microbiol. 15:312-319.

4. Bridger, J. C. 1980 . Detection by electron microscopy of caliciviruses, astroviruses and rotavirus-like particles in faeces of piglets with diarrhoea. Vet. Rec. 107:532-533.

5. Bridger, J. C., and J. F. Brown. 1984. Antigenic and pathogenic relationships of three bovine rotaviruses and a porcine rotavirus. J. Gen. Virol. 65:1151-1158.

6. Brussow, H., S. Marc-Martin, W. Eichhorn, J. Sidoti, and V. Fryder. 1987. Characterization of a second bovine rotavirus serotype. Arch. Virol. 94:29-41.

7. Dimitrov, D. H., D. Y. Graham, and M. K. Estes. 1985. Detection of rotaviruses by nucleic acid hybridization with cloned DNA of simian rotavirus SA11 genes. J. Infect. Dis. 152: 293-300.

8. Eiden, J., S. Vonderfecht, K. Theil, A. Torres-Medina, and R. H. Yolken. 1986. Genetic and antigenic relatedness of human and animal strains of antigenically distinct rotaviruses. J. Infect. Dis. 154:972-982.

9. Ericson, B. L., D. Y. Graham, B. B. Mason, and M. K. Estes. 1982. Identification, synthesis, and modifications of simian rotavirus SA11 polypeptides in infected cells. J. Virol. 42:825839.

10. Estes, M. K., E. L. Palmer, and J. F. Obijeski. 1983. Rotaviruses: a review. Curr. Top. Microbiol. Immunol. 105:124-184.

11. Flewett, T. H., and G. N. Woode. 1978. The rotaviruses. Brief review. Arch. Virol. 57:1-23.

12. Fukusho, A., Y. Shimizu, and Y. Ito. 1981. Isolation of cytopathic porcine rotavirus in cell roller culture in the presence of trypsin. Arch. Virol. 69:49-60.

13. Gaul, S. K., T. F. Simpson, G. N. Woode, and R. W. Fulton. 1982. Antigenic relationships among some animal rotaviruses: virus neutralization in vitro and cross-protection in piglets. $J$. Clin. Microbiol. 16:495-503.

14. Greenberg, H. B., J. Flores, A. R. Kalica, R. G. Wyatt, and R. Jones. 1983. Gene coding assignments for growth restriction, neutralization and subgroup specificities of the W and DS-1 
strains of human rotavirus. J. Gen. Virol. 64:313-320.

15. Greenberg, H., V. MacAuliffe, J. Valdesuso, R. Wyatt, J. Flores, A. Kalica, Y. Hoshino, and N. Singh. 1983. Serological analysis of the subgroup protein of rotavirus, using monoclonal antibodies. Infect. Immun. 39:91-99.

16. Greenberg, H. B., J. Valdesuso, K. Van Wyke, K. Midthun, M. Walsh, V. McAuliffe, R. G. Wyatt, A. R. Kalica, J. Flores, and Y. Hoshino. 1983. Production and preliminary characterization of monoclonal antibodies directed at two surface proteins of rhesus rotavirus. J. Virol. 47:267-275.

17. Hasegawa, A., S. Inouye, S. Matsuno, K. Yamaoka, R. Eko, and W. Suharyono. 1984. Isolation of human rotaviruses with a distinct RNA electrophoretic pattern from Indonesia. Microbiol. Immunol. 28:719-722.

18. Herring, A. J., N. F. Inglis, C. K. Ojeh, D. R. Snodgrass, and J. D. Menzies. 1982. Rapid diagnosis of rotavirus infection by direct detection of viral nucleic acid in silver-stained polyacrylamide gels. J. Clin. Microbiol. 16:473-477.

19. Hoshino, Y., R. G. Wyatt, H. B. Greenberg, J. Flores, and A. Z. Kapikian. 1984. Serotypic similarity and diversity of rotaviruses of mammalian and avian origin as studied by plaque-reduction neutralization. J. Infect. Dis. 149:694-702.

20. Ihara, T., T. Samejima, H. Kuwahara, and M. Tajima. 1983. Isolation of new serotypes of bovine rotavirus. Brief report. Arch. Virol. 78:145-150.

21. Kalica, A. R., H. B. Greenberg, R. G. Wyatt, J. Flores, M. M. Sereno, A. Z. Kapikian, and R. M. Chanock. 1981. Genes of human (strain $\mathrm{Wa}$ ) and bovine (strain $\mathrm{UK}$ ) rotaviruses that code for neutralization and subgroup antigens. Virology 112:385-390.

22. Kalica, A. R., R. G. Wyatt, and A. Z. Kapikian. 1978. Detection of differences among human and animal rotaviruses, using analysis of viral RNA. J. Am. Vet. Med. Assoc. 173:531-537.

23. Laemmli, U. K. 1970. Cleavage of structural proteins during the assembly of the head of bacteriophage T4. Nature (London) 227:680-685.

24. Matsuno, S., A. Hasegawa, A. R. Kalica, and R. Kono. 1980. Isolation of a recombinant between simian and bovine rotaviruses. J. Gen. Virol. 48:253-256.

25. Matsuno, S., A. Hasegawa, A. Mukoyama, and S. Inouye. 1985. A candidate for a new serotype of human rotavirus. J. Virol. 54: 623-624.

26. McCrae, M. A. 1985. Double-stranded RNA viruses, p. 151168. In B. W. J. Mahy (ed.), Virology: a practical approach. IRL Press, Oxford.

27. Mebus, C. A., N. R. Underdahl, M. B. Rhodes, and M. J. Twiehaus. 1969. Calf diarrhea (scours): reproduced with a virus from a field outbreak. Research Bulletin 233. University of
Nebraska, Lincoln.

28. Murakami, Y., N. Nishioka, Y. Hashiguchi, and C. Kuniyasu. 1983. Serotypes of bovine rotaviruses distinguished by serum neutralization. Infect. Immun. 40:851-855.

29. Offitt, P. A., and G. Blavat. 1986. Identification of the two rotavirus genes determining neutralization specificities. J. Virol. 57:376-378.

30. Ojeh, C. K., D. R. Snodgrass, and A. J. Herring. 1984. Evidence for serotypic variation among bovine rotaviruses. Arch. Virol. 79:161-171.

31. Pedley, S., J. C. Bridger, J. F. Brown, and M. A. McCrae. 1983. Molecular characterization of rotaviruses with distinct group antigens. J. Gen. Virol. 64:2093-2101.

32. Pedley, S., J. C. Bridger, D. Chasey, and M. A. McCrae. 1986. Definition of two new groups of atypical rotaviruses. J. Gen. Virol. 67:131-137.

33. Saif, L. J., E. H. Bohl, K. W. Thiel, R. F. Cross, and J. A. House. 1980. Rotavirus-like, calicivirus-like, and 23-nm viruslike particles associated with diarrhea in young pigs. J. Clin. Microbiol. 12:105-111.

34. Snodgrass, D. R., C. K. Ojeh, I. Campbell, and A. J. Herring. 1984. Bovine rotavirus serotypes and their significance for immunization. J. Clin. Microbiol. 20:342-346.

35. Theil, K. W., and C. M. McCloskey. 1988. Partial characterization of a bovine group A rotavirus with a short genome electropherotype. J. Clin. Microbiol. 26:1094-1099.

36. Thouless, M. E., R. F. Digiacomo, and D. S. Neuman. 1986. Isolation of two lapine rotaviruses: characterization of their subgroup, serotype and RNA electropherotypes. Arch. Virol. 89:161-170.

37. Woode, G. N., J. C. Bridger, G. Hall, and M. J. Dennis. 1974. The isolation of a reovirus-like agent associated with diarrhoea in colostrum-deprived calves in Great Britain. Res. Vet. Sci. 16: 102-105.

38. Woode, G. N., J. C. Bridger, J. M. Jones, T. H. Flewett, A. S. Bryden, H. A. Davies, and G. B. White. 1976. Morphological and antigenic relationships between viruses (rotaviruses) from acute gastroenteritis of children, calves, piglets, mice, and foals. Infect. Immun. 14:804-810.

39. Woode, G. N., N. E. Kelso, T. F. Simpson, S. K. Gaul, L. E. Evans, and L. Babiuk. 1983. Antigenic relationships among some bovine rotaviruses: serum neutralization and cross-protection in gnotobiotic calves. J. Clin. Microbiol. 18:358-364.

40. Woode, G. N., S. Zheng, B. I. Rosen, N. Knight, N. E. Kelso Gourley, and R. F. Ramig. 1987. Protection between different serotypes of bovine rotavirus in gnotobiotic calves: specificity of serum antibody and coproantibody responses. J. Clin. Microbiol. 25:1052-1058. 